\title{
CLAY RAW MATERIAL OF MEDIEVAL PONTIC AMPHORAE (TO THE QUESTION ABOUT PRODUCTION AREAS)
}

\author{
Evgeny V. Sukhanov \\ Institute of Archaeology, RAS, Moscow, Russian Federation
}

\begin{abstract}
Introduction. Amphorae is a significant part of pottery from the early medieval sites of Pontic region. They are traditionally considered as important source for analyzing the chronology, directions and intensity of ancient trade links. The paper is devoted to comparative analysis of clay raw material used for making medieval pontic amphorae. These ceramic containers are wide spread in the sites of the $8^{\text {th }}-10^{\text {th }}$ centuries in Crimea, Taman, the Don and the Volga river basins and in other areas. Methods and materials. Two groups of sources were investigated. The first group contains samples from 280 amphorae found on settlement sites of Saltovo-Mayaki times in the Middle and Lower Don basin. These samples have been collected by the author in the museum funds of Southern regions of Russia. The second group is represented by samples of clay raw material from Southern part of Crimea where pontic amphorae production centers were located (the foothills and Southern coast). We used A.A. Bobrinsky's method for determining different regions for digging of main plastic raw material by analyzing the ceramic under a stereoscopic microscope. Results. The main result of study is allocation of two kinds of raw materials which were used for pontic amphorae making (about $84 \%$ of studied vessels). After comparing these raw material kinds with Crimean samples, their connection with different areas was clarified. These areas belong to different geological formations. The first area is in the South-Western Crimea, and the second area covers the Southern and South-Eastern Crimean coast, to the South of the ridge of the Crimean mountains. The conducted research allowed obtaining interesting data which need to be further proved by the methods of archaeometry.

Key words: clay raw material, amphorae, trade links, pontic amphorae, areas of medieval amphorae production, binocular analysis.
\end{abstract}

Citation. Sukhanov E.V. Clay Raw Material of Medieval Pontic Amphorae (to the Question about Production Areas). Vestnik Volgogradskogo gosudarstvennogo universiteta. Seriya 4, Istoriya. Regionovedenie. Mezhdunarodnye otnosheniya [Science Journal of Volgograd State University. History. Area Studies. International Relations], 2019, vol. 24, no. 1, pp. 47-60. (in Russian). DOI: https://doi.org/10.15688/jvolsu4.2019.1.4

\section{ГЛИНИСТОЕ СЫРЬЕ СРЕДНЕВЕКОВЫХ «ПРИЧЕРНОМОРСКИХ» АМФОР (К ВОПРОСУ О РАЙОНАХ ПРОИЗВОДСТВА)}

\author{
Евгений Владимирович Суханов
}

Институт археологии РАН, г. Москва, Российская Федерация

\begin{abstract}
Аннотация. Амфорная тара представляет собой важную часть керамического комплекса раннесредневековых поселений понтийского региона. Традиционно амфоры рассматриваются как важный и информативный источник для анализа хронологии, направлений и интенсивности торговых контактов в древности. Эта статья посвящена сравнительному анализу глинистого сырья средневековых «причерноморских» амфор керамической тары, распространенной на памятниках VIII-X вв. в Крыму, Тамани, Подонье, Поволжье и другі гих территориях. Источниками изучения являлись две группы материалов. Первую из них составляют образцы о от 280 разных амфор, найденных на бытовых памятниках салтово-маяцкого времени в Среднем и Нижнем Подонье. Эти материалы были собраны автором в музейных хранениях, расположенных в южных регионах России. Вторая группа источников представлена пробами глинистого сырья, отобранными на территории южной части Крыма (предгорья и южное побережье), где располагались центры производства «причерномор-
\end{abstract}


ских» амфор. Использована методика А.А. Бобринского, направленная на выделение разных условных районов добычи основного пластичного сырья путем анализа образцов керамики с помощью стереоскопического микроскопа МБС-2. Результатом исследования стало выделение двух видов глинистого сырья, массово использовавшегося для изготовления «причерноморских» амфор (около 84 \% изученных сосудов). Сравнение выделенных видов глинистого сырья с крымскими пробами свидетельствует, что их месторождения связаны с двумя территориальными районами, относящимися к разным геологическим формациям. Первый такой район расположен в Юго-Западном Крыму, второй - занимает территорию южного и юго-восточного крымского побережья, к югу от гряды Крымских гор. Проведенное исследование позволило получить интересные данные, нуждающиеся в дальнейшей проверке с помощью археометрических методов.

Ключевые слова: глинистое сырье, амфоры, торговые связи, «причерноморские» амфоры, районы производства средневековых амфор, бинокулярный анализ.

Цитирование. Суханов Е. В. Глинистое сырье средневековых причерноморских амфор (к вопросу о районах производства) // Вестник Волгоградского государственного университета. Серия 4, История. Регионоведение. Международные отношения. - 2018. - Т. 24, № 1. - C. 47-60. - DOI: https://doi.org/10.15688/ jvolsu4.2019.1.4

Введение. Амфорная тара составляет одну из представительных групп керамики на поселенческих памятниках VIII-X вв. в Северном Причерноморье. Горны, в которых обжигались эти амфоры, известны на территории Таврики [7]. По региону производства и ареалу распространения за ними закрепилось наименование «причерноморских» амфор, или амфор «причерноморского» типа. В настоящее время точка зрения о крымском происхождении этих сосудов выглядит наиболее обоснованной и поддерживается большинством исследователей [6, с. 37].

Основной поток экспорта продукции в таких амфорах был направлен в Восточное Причерноморье, Приазовье, Подонье, реже они попадали в Поднепровье и Поволжье. Находки похожих сосудов известны и на других памятниках восточно-средиземноморского мира, однако пока что не вполне ясно, можно ли отождествлять эти амфоры с «причерноморскими» [8, fig. 5, 7; 9, fig. 25, 1-9, 12-15, fig. $23,2-6,8-12$; 10 , fig. $6,2-3 ; 11$, p. 60-61].

Несмотря на общепризнанность точки зрения о крымском происхождении «причерноморских» амфор, дискуссионным является вопрос о возможностях определения конкретных мест изготовления этих сосудов на основании особенностей глин, из которых они сделаны. В литературе отражены принципиально противоположные точки зрения на этот счет. Некоторые исследователи считают это практически невозможным в силу отсутствия конкретных данных и указывают на необходимость создания «банков данных» по формовочным массам амфор [7, с. 76]. С другой стороны, известны примеры весьма конкретных определений районов производства [5, c. 165]. В последнем случае не вполне понятно, на какие сведения опираются авторы. Данные петрографического анализа, опубликованные в 1960-е гг., лишь подтверждали крымское происхождение «причерноморских» амфор, но не показывали конкретные отличия, присущие глинистому сырью из разных районов Таврики, - сопоставление осуществлялось лишь с материалами двух гончарных центров, Мисхора и Чабан-Куле [4].

Перечисленные обстоятельства указывают, что к настоящему времени назрела необходимость, во-первых, в изучении особенностей сырья самих «причерноморских» амфор; во-вторых, в анализе особенностей глинистого сырья, залегающего в разных районах Крыма, и формулировке допустимой степени детальности при определении потенциальных районов производства и экспорта рассматриваемой керамической тары. На решение именно этих вопросов было нацелено исследование, результатам которого посвящена данная статья.

Материалы и методы. Использованы две группы источников. Первую составляют обломки амфор с бытовых памятников салтово-маяцкой культуры на Среднем и Нижнем Дону. В ходе исследований материалов этого региона автором данной статьи на протяжении нескольких лет формировался «банк данных» по глинистому сырью. К настоящему времени он состоит из фрагментов от 280 разных амфор с 11 бытовых памятников. К числу памятников Среднего Подонья относятся 
селища Архангельское, Шпенгаревское, Дмитриевское, Хуторцы, а также Маяцкий археологический комплекс. Нижнедонские памятники представлены Крымским городищем, селищами Крымский-4, Калиновка, Полное, Терновое-3, Маркина Балка, Клиновое, Рогожкино-3, Рогожкино-5. Коллекции перечисленных памятников были изучены в фондовых хранилищах музеев и университетов Воронежа, Белгорода, Ростова-на-Дону, Аксая, Азова, Волгодонска, Таганрога.

Вторую группу источников составляют пробы ${ }^{1}$ глинистого сырья, отобранные автором в разных местах на территории предгорий и южного побережья Крыма (рис. 6). Выбор мест взятия проб был приурочен, во-первых, к известным гончарным центрам; во-вторых, к конкретным залежам глин, которые выявлялись путем непосредственного осмотра местности. Из 10 отобранных образцов 9 впоследствии оказались пригодными для анализа (№ 1-9). Еще одна проба, используемая в данной работе, была сделана в 2004 г. сотрудницей отдела теории и методики ИА РАН O.А. Лопатиной.

\section{Описание пунктов отбора проб.}

Пункт 1. Село Трудолюбовка Бахчисарайского района, пойма р. Бодрак, в 0,5 км к северо-западу от села. В непосредственной близости к указанному населенному пункту известен крупный гончарный центр, включающий 15 горнов. В этом же предгорном районе по данным, имеющимся в научной литературе, известны еще 4 центра.

Пункт 2. Село Гончарное Балаклавского района, надпойменная терраса р. Сухая, югозападная окраина села. В ближайшей округе от этого пункта известно 3 гончарных центра: Сарыч, Ласпи, Батилиман.

Пункт 3. Черта г. Алупка, Южнобережное шоссе. Пункт тяготеет к одному из наиболее известных гончарных центров южного Крыма - Мисхору.

Пункт 4. Село Васильевка, близ Ялты, Южнобережное шоссе. Участок между пунктами 3 и 4 включает район расположения шести гончарных центров.

Пункт 5. Село Нижняя Кутузовка, близ Алушты, надпойменная терраса р. Демерджи. В непосредственной близости к этому пункту находилось как минимум 6 гончарных центров.
Пункт 6. Село Приветное Судакского района, в 1 км к югу - юго-западу от села, пойма р. Ускут. В непосредственной близости располагался крупный гончарный центр Чабан-Куле.

Пункт 7. Село Рыбачье (городской округ Алушты). В непосредственной близости находятся два гончарных центра, в том числе один из наиболее известных - Канакская балка.

Пункт 8. Село Дачное Судакского района, пойма р. Суук-Су. В радиусе 10-15 км находились три гончарных центра

Пункт 9. Старый Крым, южная окраина, надпойменная терраса $p$. Чурук-Су. Участок между пунктами 8 и 9 покрывает территорию распространения «куста» гончарных центров, наиболее удаленных к востоку крымского побережья.

Пункт 10. Окрестности Севастополя, курортный поселок Любимовка, береговой обрыв в районе пляжа. Место взятия пробы близко к району расположения херсонесских гончарных центров.

В работе использована методика А.А. Бобринского, нацеленная на выделение разных культурных традиций отбора пластичного сырья [1, с. 67-83; 2, с. 25-30]. Выбор этой методики обоснован возможностью на наиболее общем и доступном уровне выявлять разные или, напротив, очень похожие источники сырья, использовавшиеся древними гончарами для изготовления посуды. В рамках данной методики изучение сырья ведется на двух уровнях: качественном, более общем, и количественном, более детальном. На основании качественного состава естественных примесей в глине выделяются так называемые условные районы добычи сырья. Анализ концентрации и окатанности этих примесей позволяет в рамках таких районов установить разные условные «места» добычи пластичного сырья. В этой статье речь пойдет только о районах, так как на данном этапе исследования они представляют наибольший интерес.

Таким образом, программа исследования глинистого сырья имела следующий вид:

I. Подготовительный этап.

В фондах музеев отбирались небольшие образцы от разных сосудов на основании различий в морфологии профильных частей, в цве- 
товых особенностях и следах обработки внутренней и внешней поверхности сосудов.

II. Описательный этап.

В лаборатории «История керамики» ИА РАН небольшие обломки от всех амфор обжигались в муфельной печи при температуре $850{ }^{\circ} \mathrm{C}$. После обжига определялась степень ожелезненности глины каждого сосуда путем сопоставления со шкалой, контрольные образцы которой были обожжены при этой же температуре. Затем свежие сколы черепков от каждой амфоры изучались под бинокулярным микроскопом МБС-2 с увеличением 4-56 крат с целью определения состава естественных примесей в глине и их концентрации. Качественный и количественный состав примесей в каждом образце фиксировался и подробно описывался в лабораторном журнале. Определению поддавались виды естественных включений, их форма, внешняя и внутренняя структура, цвет, размер, концентрация, характер контакта с глиняной массой.

III. Аналитический этап.

Вся зафиксированная информация была представлена в сводной таблице и подвергнута систематизации и сравнительному анализу с целью выделения условных районов добычи глины.

Образцы проб глин, отобранных на территории Крыма, были приведены в пластичное состояние путем добавления воды. После этого из них были изготовлены брикеты размером $10 \times 5$ см. После сушки брикеты обжигались в муфельной печи: одна партия - до температуры $500{ }^{\circ} \mathrm{C}$, другая - до $850{ }^{\circ} \mathrm{C}$. Разные температуры обжига были необходимы для фиксации изменений цветовых характеристик естественных примесей в глинах. После этого экспериментальные образцы были изучены под бинокулярным микроскопом. Фиксировался качественный состав естественных примесей и их концентрация.

Все этапы исследования, от подготовительного до аналитического, выполнены непосредственно автором статьи.

Анализ. В формовочной массе изученных сосудов были отмечены следующие естественные примеси.

1. Известняк - является наиболее распространенной естественной примесью. Представляет собой включения белого, светло- бежевого и светло-серого цвета, имеющие рыхловатую, «порошковидную» структуру. Во всех без исключения фрагментах сосудов известняк встречен в виде частиц размером от 0,1 до 1-2 мм. Частицы, как правило, имеют неправильную форму, иногда приближенную к подтреугольной, подовальной или округлой. Подавляющая часть примеси известняка в образцах представлена частицами до 0,5 мм с относительно редкими включениями более крупного размера. Вступает в реакцию с $10 \%$-ой соляной кислотой (вскипает). Порода известняка не определялась.

2. Песок. Одноцветные частицы светлосерых тонов, различной степени окатанности, обладающие глянцевым блеском. В большинстве изученных образцов размер частиц составляет менее 0,5 мм, в крайне редких случаях достигает $0,7-0,8$ мм. Концентрация песка колеблется пределах от 1-2 до 50-70 включений на $1 \mathrm{~cm}^{2}$. Единично зафиксирована более высокая концентрация порядка 180230 единиц на $1 \mathrm{~cm}^{2}$, что допустимо рассматривать как искусственную добавку, введенную гончаром в формовочную массу.

3. Бурый железняк. Под этим условным наименованием зафиксированы два вида естественных включений, достаточно отчетливо отличающихся друг от друга по внешним признакам.

Вид 1 - это преимущественно окатанные, шарообразные, реже - эллипсоидные частицы, однородные по цвету, который может варьировать от серовато-коричневого до яркокрасного. В изломе черепка фиксируются в виде выпуклых гранул или округлых пятен с однородной внутренней структурой на его поверхности. Концентрация варьирует от 1-2 до 15-20 включений на $1 \mathrm{~cm}^{2}$.

Вид 2 - железистые частицы, обычно окатанные, реже - слабоокатанные и остроугольные включения бордового цвета, иногда с темно-бордовой, почти черной внешней «коркой» и красновато-бордовой сердцевиной или же темно-бордовым внешним слоем и темной сердцевиной. Отличаются от бурого железняка первого вида формой и размером частиц - они, как правило, имеют уплощенноэллипсоидную или подпризматическую форму и размер в пределах 0,5-2 мм. В изломе частицы имеют «слоистую» структуру, на- 
сыщены очень мелкими светлыми включениями. Концентрация варьирует от 1-2 до 50-60 включений на $1 \mathrm{~cm}^{2}$.

4. Черные рудные минераль. Окатанные, редко - слабоокатанные включения черного цвета, обладающие металлическим блеском. Размер частиц колеблется в пределах $0,1-0,5 / 0,6$ мм, в большинстве случаев $0,2-0,3$ мм.

5. Песчаник - включения подтреугольной, подовальной или подпрямоугольной формы, состоящие из множества сцементированных песчаных частиц. Общий цвет серый, тон может варьировать.

На основании разных сочетаний естественных примесей в изученных сосудах выделены 11 условных районов добычи пластичного сырья. Им присвоены порядковые номера по мере уменьшения численности сосудов, относящихся к каждому из районов.

Наиболее массовыми оказались районы № 1, 2, 3, 4, к которым относится 84,3 \% изученных сосудов (рис. 1). К каждому из последующих районов относится менее $5 \%$ сосудов. Таким образом, к относительно массовым районам следует отнести № 1-4, а к более редким - районы № 5-11, представленные количественно, как правило, менее чем 10 сосудами.

«Массовые» районы:

Район 1. Известняк + песок + бурый железняк, вид $1+$ черные рудные минералы. К району относятся 110 сосудов, что составляет $39,3 \%$ от всей проанализированной выборки.

Район 2. Известняк + песок + бурый железняк, вид 2. Сюда относятся 53 сосуда, или $18,9 \%$ от числа изученных.

Район 3. Известняк + песок + бурый железняк, вид $2+$ песчаник. Зафиксирован по 45 сосудам, что составляет $16,1 \%$ от всей выборки.

Район 4. Известняк + песок + бурый железняк, вид 1 . К району относятся 28 сосудов, то есть $10 \%$.

«Редкие» районы:

Район 5. Известняк + песок + песчаник + бурый железняк, вид $1-12$ сосудов (4,3 \%).

Район 6. Известняк + бурый железняк, вид $1-7$ сосудов $(2,5 \%)$.

Район 7. Известняк + песок -7 сосудов $(2,5 \%)$
Район 8. Известняк + песок + бурый железняк, вид $1+$ черные рудные минералы + песчаник - 6 сосудов $(2,1 \%)$.

Район 9. Известняк + бурый железняк, вид $1+$ черные рудные минералы -5 сосудов $(1,8 \%)$.

Район 10. Известняк + песок + черные рудные минералы + песчаник -5 сосудов $(1,8 \%)$.

Район 11. Известняк + черные рудные минералы - 2 сосуда $(0,7 \%)$.

Таким образом, по изученным материалам на качественном уровне анализа оказалось возможным выделить 11 районов добычи глинистого сырья. Подавляющее большинство сосудов изготовлены из сырья первых четырех районов. Обобщение полученных данных в рамках четырех массовых районов добычи сырья позволяет выделить два вида глин, характеризующихся существенными различиями.

К первому такому виду относится сырье условных районов 1 и 4 (рис. 2). Они характеризуются большим количеством очень мелкого известняка, наличием мелкого окатанного бурого железняка и отсутствием крупных железистых включений.

Второй вид глин представлен сырьем условных районов 2 и 3 (рис. 3). От первого они кардинально отличаются наличием крупных железистых включений (бурый железняк, вид 2), иногда в достаточно высокой концентрации. На уровне микроскопического анализа эту глину отличает наличие разнообразных форм у включений известняка, их повышенная относительно первого вида размерность, наличие слабоокатанных и остроугольных частии песка.

Описанные два вида глин удалось выявить при анализе проб сырья, отобранных на территории Крыма, на основании состава естественных примесей, структур их изломов, размерности, цвета и окатанности, то есть всех тех признаков, которые фиксируются при изучении с помощью стереоскопического микроскопа. Первый вид глины представлен в первом и десятом пунктах, расположенных в предгорьях и на побережье Юго-Западного Крыма (рис. $4,1,2$ ). По качественному составу естественных примесей она соответствует первому условному району добычи сырья. 
Большое сходство с глиной этого пункта проявляет также сырье четвертого условного района. Второй вид глин представлен в пунктах 2-9 (рис. $4,3-5 ; 5$ ) и охватывает практически всю южную и юго-восточную часть Крыма, расположенную с южной, «приморской» стороны от горного хребта. По качественному составу естественных примесей со вторым условным районом $(И+П+$ БЖ, вид 2) соотносятся пункты $2,3,4,8,9$; с тре-

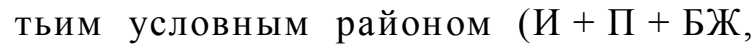
вид $2+$ ПС) - пункты 5, 6, 7 .

Таким образом, выделенные как по археологическим материалам, так и по крымским пробам два вида глин оказались связаны с двумя разными территориальными районами - это предгорья и южное / юговосточное побережье Крыма. Еще 7 условных районов добычи сырья, выделенных по амфорам, не находят ничего общего с крымскими глинами.

В ходе анализа был отмечен ряд характерных особенностей, присущих глинам из разных пунктов. На общем фоне выделяется глина 1-го и 10-го пунктов, отобранная в Юго-Западном Крыму. Она характеризуется малыми размерами включений известняка, наличием относительно мелких окатанных включений бурого железняка (вид 1), песка и черных рудных минералов. Глины из пунктов 2-9, отобранные на южном и юговосточном побережье Крыма, оказались почти неразличимыми визуально, без использования микроскопа. Их характеризуют следующие черты. Во-первых, для всех этих образцов характерно наличие специфических железистых включений (бурого железняка второго вида) - пожалуй, главный критерий, сближающий внешнюю «фактуру» этих глин. Во-вторых, во всех глинах пунктов 2-9 известняк сходен по разнообразию форм включений и по более низкой, чем в предгорной территории, концентрации (максимум - до 100-150 видимых включений на $1 \mathrm{~cm}^{2}$, обычно меньше). В-третьих, довольно характерным для этого региона видом обладает и примесь естественного песка - более крупный размер и высокая доля слабоокатанных и остроугольных частиц, в отличие от предгорий юго-запада, где песок более мелкий и окатанный. Наконец, в глинах южного и юго-во- сточного побережья полностью отсутствуют черные мелкие окатанные частицы, обладающие металлическим блеском.

Некоторой спецификой характеризуются глины из пунктов 8 и 9. Здесь включения бурого железняка встречаются в виде частиц, приближенных к кубической форме, которую очень легко спутать с шамотом, меньше размер песка и его частицы более окатанны. Обращаем внимание на такие различия, поскольку на качественном уровне эти глины относятся к одному и тому же условному району добычи сырья.

Помимо перечисленного, центральная часть юго-восточного побережья Крыма (пункты $5,6,7)$ отличается наличием в отобранных глинах включений песчаника. Характерно, что эта примесь имеет крайне низкую концентрацию (1-2 на $1 \mathrm{~cm}^{2}$ ), что находит соответствие в исследованных археологических материалах.

Таким образом, судя по полученным данным, отличия изученных глин по составу естественных примесей связаны не с широтной «привязкой» районов добычи к западной или восточной частям Крыма, а с расположением относительно гряды Крымских гор. Именно поэтому образцы глины, отобранные в югозападной части полуострова, с северной стороны от нее (рис. $4,1,2$ ), существенно отличаются от образца на юго-западе полуострова, отобранного со стороны морского побережья (рис. 4, 3, 5).

Чем могут объясняться прослеженные различия? Обращение к Геологической карте Крыма [3] показывает, что отложения южного и юго-восточного участков побережья относятся к юрской системе, в то время как отложения предгорий юго-западного Крыма связаны с палеогеном и неогеном. Таким образом, кардинальные отличия выделенных двух видов глин связаны с разными геологическими формациями районов добычи сырья для изготовления «причерноморских» амфор (рис. 6).

В заключение отметим, что наш вывод в значительной мере подтверждается данными, которые получены в Лионской лаборатории при археометрических исследованиях средневековой поливной керамики, изготовлявшейся в разных частях Крыма. Выясни- 
E.B. Суханов. Глинистое сырье средневековых «причерноморских» амфор (к вопросу о районах производства)

лось, что отличия химического состава глинистого сырья, из которого делалась эта посуда, напрямую связаны с географией разных геологических формаций этого полуострова [12, p. 722-723; 13, p. 389].

Результаты. Резюмируем основные выводы, сделанные по результатам проделанного исследования.

1. По итогам изучения глинистого сырья «причерноморских» амфор Среднего и Нижнего Дона по методике А.А. Бобринского выделены 11 условных районов добычи глин. Большинство сосудов оказалось изготовлено из сырья четырех условных районов. Обобщение полученных данных позволяет выделить два вида глин, кардинально отличающихся друг от друга, главным образом, на уровне качественных признаков (состав примесей, окатанность, характер структуры изломов и др.).

2. Выделенные виды глин по составу естественных примесей находят соответствия в пробах сырья, отобранных на территории Крыма.

3. Картографирование полученных данных демонстрирует сопряженность выделенных видов глин с двумя разными территориальными районами, разделенными грядой Крымских гор. Первый такой район локализован в Юго-Западном Крыму, а второй включает территорию южного и юго-восточного побережья.

4. Кардинальные отличия между глинами, относящимися к указанным районам, свя- заны принадлежностью этих районов к двум разным геологическим формациям.

Практическая ценность полученных результатов заключается в возможности более точного учета на памятниках VIII$\mathrm{X}$ вв. амфор, изготовленных из глин разных районов Таврики. Это может послужить основой для изучения по данным «причерноморских» амфор направлений торговых контактов и их эволюции во времени, как в рамках отдельных памятников, так и для целых регионов.

В заключение нужно отметить, что представленные в этой статье данные являются в определенной мере предварительными и требуют дальнейшей проверки с помощью естественнонаучных методов исследования керамической массы.

\section{ПРИМЕЧАНИЕ}

${ }^{1}$ Неоценимую помощь в проведении отбора проб глинистого сырья в Крыму мне оказал коллектив организации «Белгородская археологическая экспертиза». Выражаю признательность своим коллегам, а также персонально А.Г. Кудряшову за оказанную поддержку. Большая благодарность сотруднику отдела теории и методики ИА РАН О.А. Лопатиной, любезно предоставившей отобранные в окрестностях Севастополя пробы глинистого сырья. 


\section{ПРИЛОЖЕНИЕ}

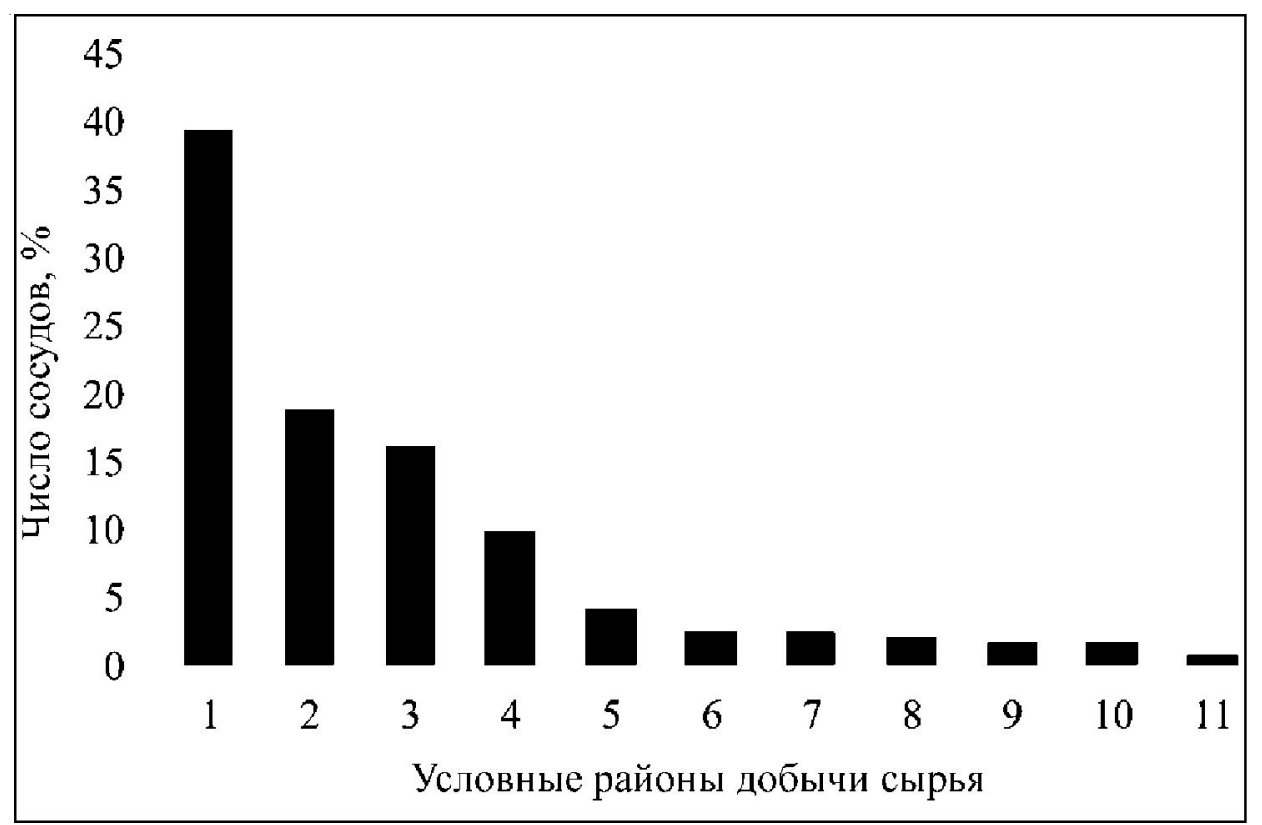

Рис. 1. Соотношение амфор, изготовленных из глин разных сырьевых районов

Fig. 1. The ratio of amphorae made from clay of different raw-material regions
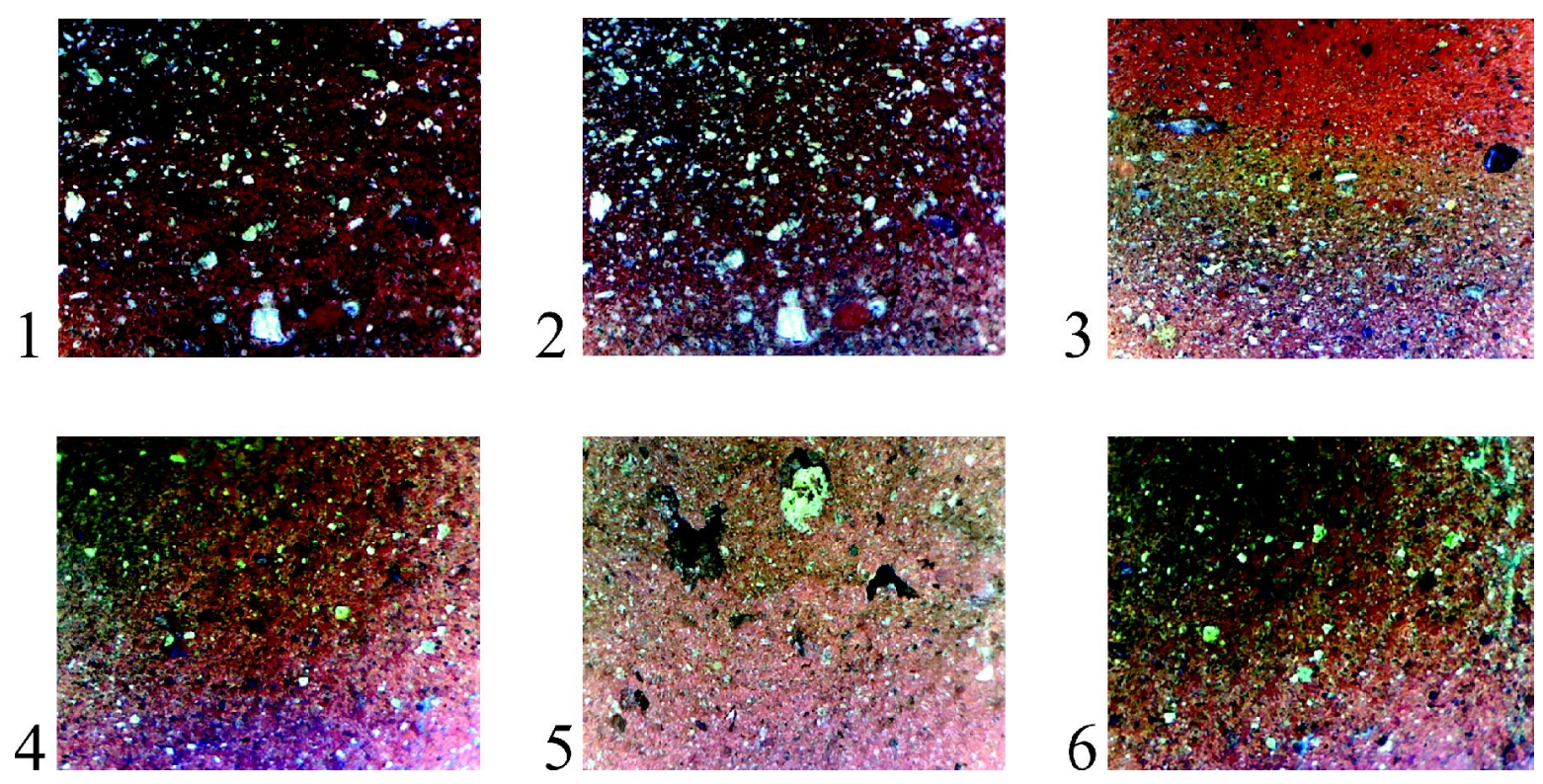

Рис. 2. Фотографии изломов амфор, изготовленных из глин первого вида:

1, 2, 3 - первый условный район добычи сырья; 4, 5, 6- четвертый условный район добычи сырья

Fig. 2. Photos of amphorae fractures made of first-kind clay:

$1,2,3$ - first raw-material area; 4, 5, 6- fourth raw-material area 
E.B. Суханов. Глинистое сырье средневековых «причерноморских» амфор (к вопросу о районах производства)
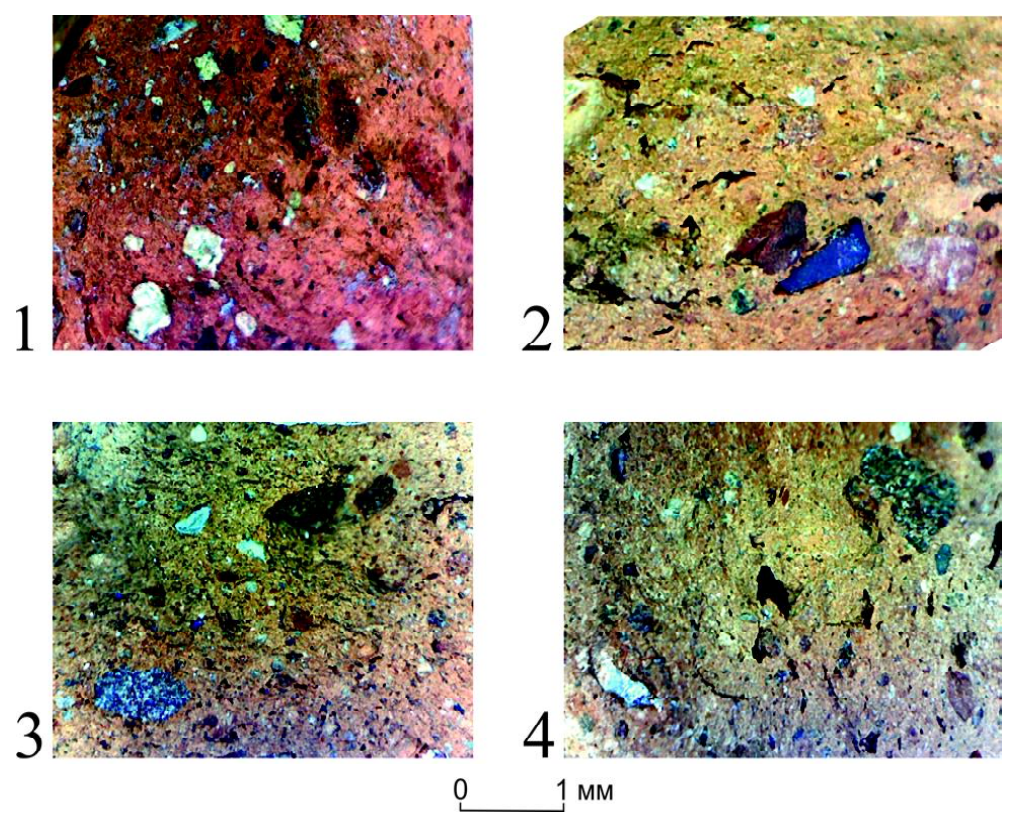

Рис. 3. Фотографии изломов амфор, изготовленных из глин второго вида:

1, 2 - второй условный район добычи сырья; 3, 4- третий условный район добычи сырья

Fig. 3. Photos of amphorae fractures made of second-kind clay: 1,2- second raw-material area; 3, 4-third raw-material area 

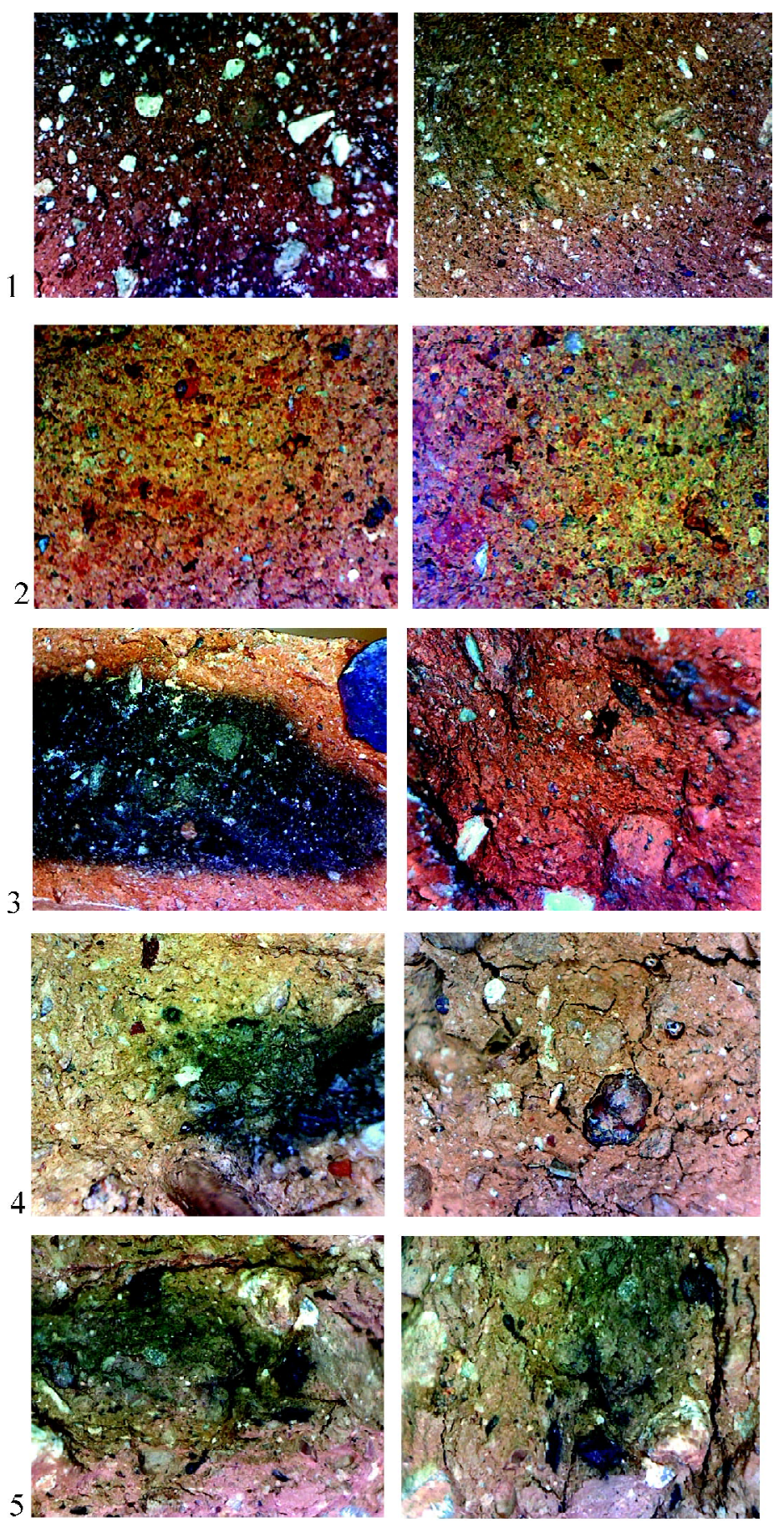

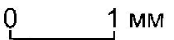

Рис. 4. Фотографии экспериментальных эталонов, изготовленных из глинистого сырья Крыма: 1 - пункт 1; 2 - пункт 10; 3 - пункт 2; 4 - пункт 3; 5 - пункт 4

Fig. 4. Photos of experimental samples made of the Crimean clay raw material:

1 - sampling site $1 ; 2$ - sampling site 10;3-sampling site $2 ; 4$ - sampling site $3 ; 5$ - sampling site 4 
E.B. Суханов. Глинистое сырье средневековых «причерноморских» амфор (к вопросу о районах производства)
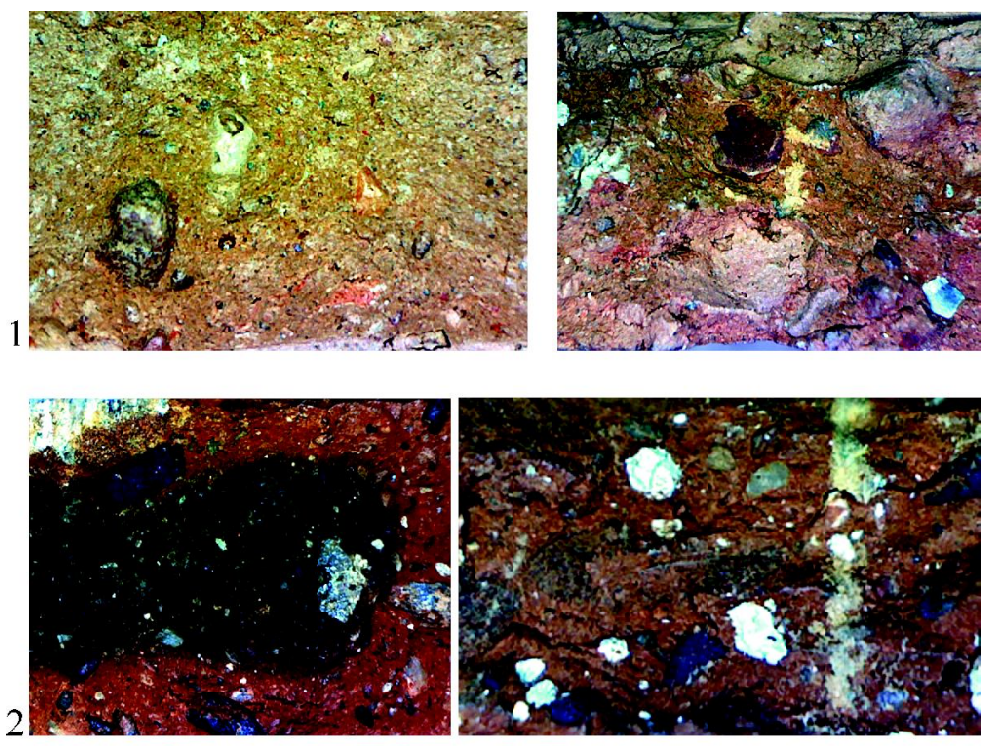

3
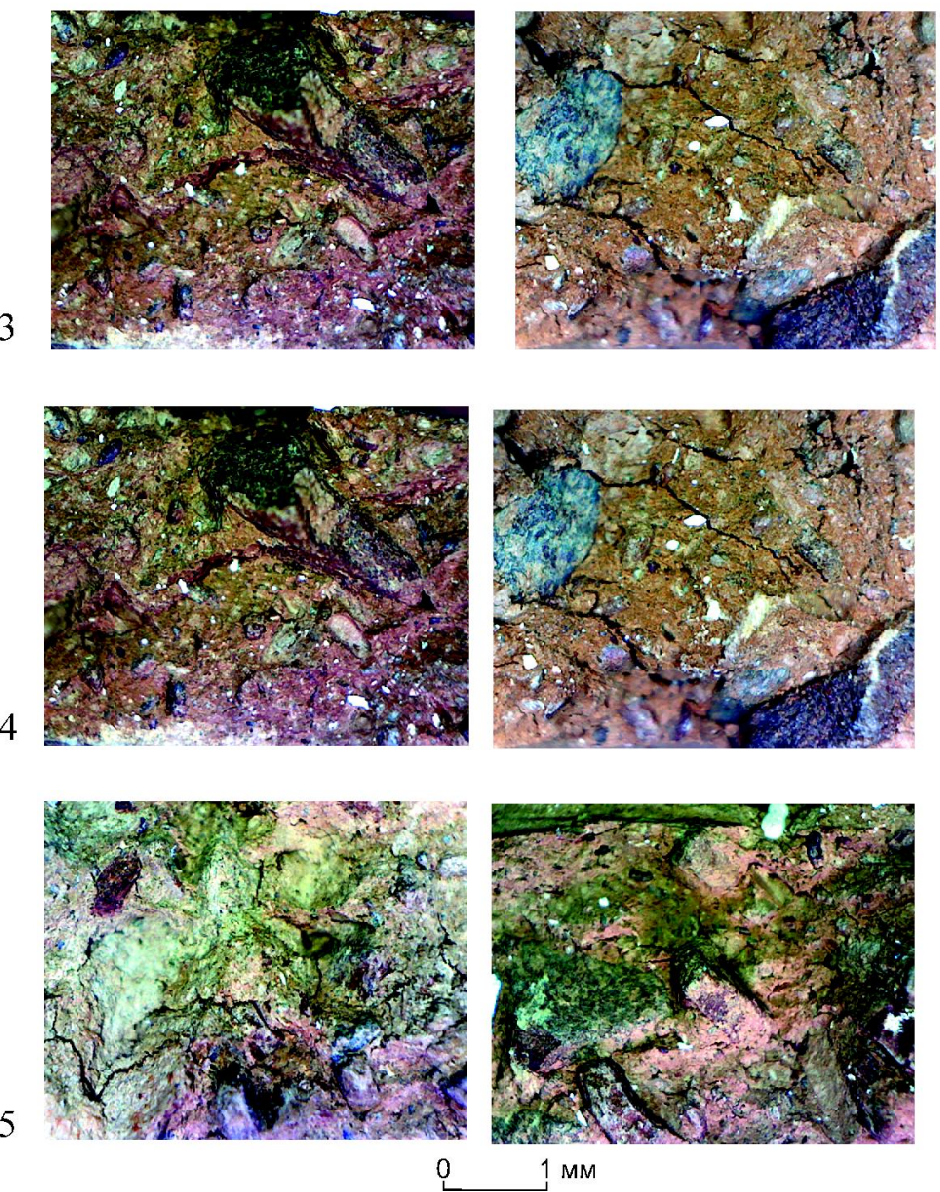

Рис. 5. Фотографии экспериментальных эталонов, изготовленных из глинистого сырья Крыма: 1 - пункт 5; 2 - пункт 6; 3 - пункт 7; 4 - пункт 8; 5 - пункт 9

Fig. 5. Photos of experimental samples made of the Crimean clay raw material:

1 -sampling site 5;2-sampling site 6;3-sampling site 7;4-sampling site $8 ; 5$ - sampling site 9 


\section{АРХЕОЛОГИЯ}

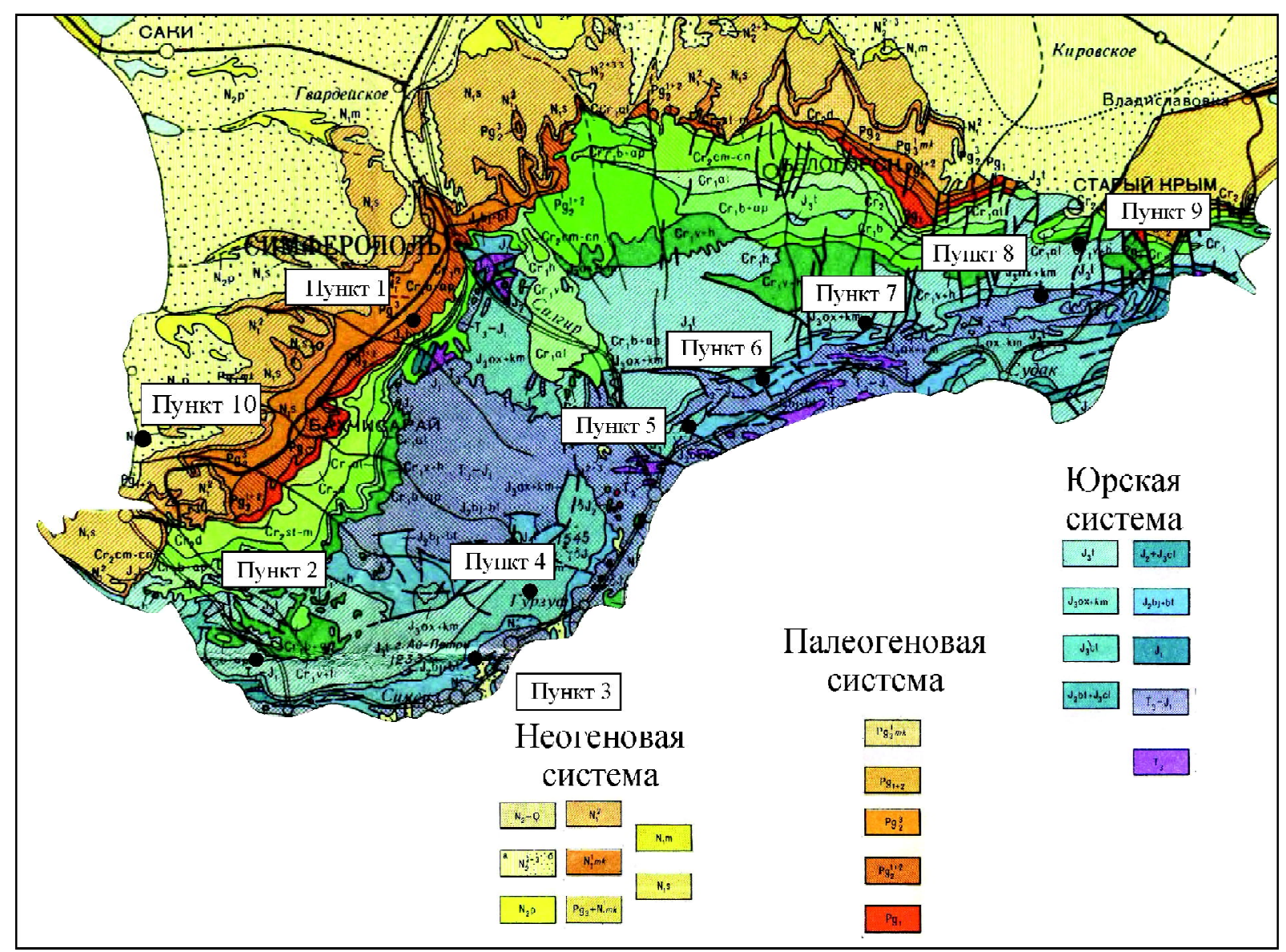

Рис. 6. Соотношение пунктов отбора проб глин и разных геологических формаций

Fig. 6. The ratio of clay sampling sites and different geological formations 


\section{СПИСОК ЛИТЕРАТУРЫ}

1. Бобринский, А. А. Гончарство Восточной Европы. Источники и методы изучения / А. А. Бобринский. - М. : Наука, 1978. - 275 с.

2. Бобринский, А. А. Гончарная технология как объект историко-культурного изучения / А. А. Бобринский // Актуальные проблемы изучения древнего гончарства : коллектив. моногр. Самара: СамГПУ, 1999.-С. 5-109.

3. Геологическая карта Крыма / сост. в Украинском научно-исследовательском геологоразведочном институте И.В. Архиповым, Е.А. Успенском, ред. М. В. Муратов. - 1: 1000 000. - Л. : Ленинградская картфабрика ВАГТ, 1967. - 1 к.

4. Ковнурко, Г. М. Петрографический анализ средневековых амфор из Крыма и Приазовья / Г. М. Ковнурко // КСИА. - 1968. - Вып. 113. C. 119-122.

5. Ларенок, П. А. Раннесредневековый комплекс поселения Терновое III (по материалам раскопок 2004 г.) / П. А. Ларенок, С. В. Цыбрий, А. В. Цыбрий // Археологические записки. - Ростов н/Д : РРОО «Донское археологическое общество», 2011. - Вып. 7. - С. 145-169.

6. Науменко, В. Е. Амфоры / В. Е. Науменко // В. Н. Зинько, Л. Ю. Пономарев. Тиритака. Раскоп XXVI. T. 1 : Археологические комплексы VIII-X вв. Симферополь ; Керчь : АДЕФ-Украина, 2009. С. 35-50. - (БИ; suppl. 5).

7. Паршина, Е. А. Гончарные центры Таврики VIII-Х вв. / Е. А. Паршина, И. Б. Тесленко, С. М. Зеленко // Морская торговля в Северном Причерноморье : сб. науч. ст. - Киев : Наукова думка, 2001. - С. 52-81.

8. Arthur, P. Aspects of Byzantine Economy: an evaluation of amphora evidence from Italy / P. Arthur // Recherches sur la Céramique Byzantine.-BCH. Suppl. XVIII. - Paris : École française d'Athènes, 1989. -P. 79-93.

9. Hayes, J. W. Excavations at Sarachane in Istanbul. Vol. 2. The Pottery/ J. W. Hayes. - Princeton : Princeton University Press, 1992. -455 p.

10. Sagui, I. Nuovi dati ceramologici per la storia economica di Roma tra VIIe-VIII secolo/I. Sagui, M. Ricci, D. Romei // La ceramique medievale en Mediterranee. Aix-en-Provence: Narration, 1997. -P. 35-48.

11. Vroom, J. Byzantine to modern pottery in the Aegean. An introduction and field guide / J. Vroom. Utrecht : Parnassus press, Bijleveld, 2005. - 223 p.

12. Waksman, S. Y. Late medieval pottery production in South Western Crimea: laboratory investigations of ceramics from Cembalo (region of Sebastopol / Chersonesos) / S. Y. Waksman, N. Ginkut // Actas do X Congresso Internacional a cerâmica Medieval no Mediterraneo / Eds. M. J. Gonçalves, S. Gómez-Martinez. - Mértola : Gráfica commercial de Loulé, 2015. - P. 719-723.
13. Waksman, S. Y. Byzantine Chersonesos, an investigation of the local production of ceramics by chemical analysis / Y. S. Waksman, A. Romanchuk // Çanak: Late Antique and Medieval Pottery and Tiles in Mediterranean Archaeological Contexts. Proceedings of the First International Symposium on Late Antique, Byzantine, Seljuk, and Ottoman Pottery and Tiles in Archaeological Context (BYZAS 7). Istanbul : Ege Yayınları / German Institute of Archaeology, 2007. - P. 383-398.

\section{REFERENCES}

1. Bobrinskiy A.A. Goncharstvo Vostochnoy Evropy. Istochniki i metody izucheniya [The Pottery of Eastern Europe. Sources and Methods of Study]. Moscow, Nauka Publ., 1978. 275 p.

2. Bobrinskiy A.A. Goncharnaya tekhnologiya kak obyekt istoriko-kulturnogo izucheniya [Pottery Technology as an Object of Historical and Cultural Study]. Aktualnye problemy izucheniya drevnego goncharstva: kollektiv. monogr. Samara, SamGPU Publ., 1999, pp. 5-109.

3. Arkhipov I.V., Uspensky E.A., Muratov M.V., eds. Geologicheskaya karta Kryma [Geological Map of the Crimea]. 1: 1000000 . Leningrad, Leningradskaya kartfabrika VAGTPubl., 1967. 1 map.

4. Kovnurko G.M. Petrograficheskiy analiz srednevekovykh amfor iz Kryma i Priazovya [Petrographical Analysis of Medieval Amphorae from the Crimea and Azov Region]. KSIA, 1968, vol. 113, pp. 119-122.

5. Larenok P.A., Tsybriy S.V., Tsybriy A.V. Rannesrednevekovyy kompleks poseleniya Ternovoe III (po materialam raskopok 2004 g.) [Early Medieval Complex of the Ternovoe III Settlement (Based on Excavations of 2004)]. Arkheologicheskie zapiski [Archaeological Notes]. Rostov-on-Don, Donskoe arkheologicheskoe obshchestvo Publ., 2011, iss. 7, pp. 145-169.

6. Naumenko V.E. Amfory [Amphorae]. Zinko V.N., Ponomarev L.Yu. Tiritaka. Raskop XXVI. T. 1. Arkheologicheskie kompleksy VIII-X vv [Tyritake. Excavation XXVI. Vol. 1. Archaeological Complexes of the 8th -10th cc. AD]. Simferopol; Kerch, ADEF-Ukraina Publ., 2009, pp. 35-50.

7. Parshina E.A., Teslenko I.B., Zelenko S.M. Goncharnye tsentry Tavriki VIII-X vv. [Pottery Centers of Taurica of the 8th -10th cc. AD]. Morskaya torgovlya $v$ Severnom Prichernomorye : sb. nauch. st. [Maritime Trade in the North Pontic Area. Collection of Scientific Articles]. Kiev, Naukova dumka Publ., 2001, pp. 52-81.

8. Arthur P. Aspects of Byzantine Economy: an evaluation of amphora evidence from Italy. Recherches sur la Céramique Byzantine. BCH. 


\section{АРХЕОЛОГИЯ}

Suppl. XVIII. Paris, École française d'Athènes, 1989, pp. 79-93.

9. Hayes J.W. Excavations at Sarachane in Istanbul. Vol. 2. The Pottery. Princeton, Princeton University Press, 1992. 455 p.

10. Sagui I., Ricci M., Romei D. Nuovi dati ceramologici per la storia economica di Roma tra VIIeVIII secolo. La ceramique medievale en Mediterranee. Aix-en-Provence, Narration, 1997, pp. 35-48.

11. Vroom J. Byzantine to modern pottery in the Aegean. An introduction and field guide. Utrecht, Parnassus press, Bijleveld, 2005. 223 p.

12. Waksman S.Y., Ginkut N. Late medieval pottery production in South Western Crimea: laboratory investigations of ceramics from Cembalo (region of Sebastopol / Chersonesos). M.J. Gonçalves, S. GómezMartinez. Actas do X Congresso Internacional a cerâmica Medieval no Mediterraneo. Mértola, Gráfica commercial de Loulé, 2015, pp. 719-723.

13. Waksman S.Y., Romanchuk A. Byzantine Chersonesos, an investigation of the local production of ceramics by chemical analysis. Çanak: Late Antique and Medieval Pottery and Tiles in Mediterranean Archaeological Contexts. Proceedings of the First International Symposium on Late Antique, Byzantine, Seljuk, and Ottoman Pottery and Tiles in Archaeological Context (BYZAS 7). Istanbul, Ege Yayınlar1 / German Institute of Archaeology, 2007, pp. 383-398.

\section{Information about the Author}

Evgeniy V. Sukhanov, Junior Researcher of Department of Theory and Methodology, Institute of Archaeology, RAS, Dm. Ulyanova St., 19, 117036 Moscow, Russian Federation, sukhanov_ev@mail.ru, https://orcid.org/0000-0002-0072-1428

\section{Информация об авторе}

Евгений Владимирович Суханов, младший научный сотрудник отдела теории и методики, Институт археологии РАН, ул. Дм. Ульянова, 19, 117036 г. Москва, Российская Федерация, sukhanov_ev@mail.ru, https://orcid.org/0000-0002-0072-1428 